\title{
Antidiabetic Potential of Methanolic Extract of Leave and Bark of Bangladeshi Medicinal Plant Bauhinia acuminata L on Mice
}

Manobendro Nath Ray ${ }^{1 *}$, Tarannum $\mathrm{Naz}^{1}$, Alam Khan ${ }^{1}$ and Md. Hanif $\mathrm{Ali}^{2}$

${ }^{1}$ Department of Pharmacy, University of Rajshahi, Rajshahi-6205, Bangladesh

${ }^{2}$ Department of Biochemistry and Molecular Biology, University of Rajshshi, Rajshahi, Bangladesh

"Corresponding authors: Manobendro Nath Ray, Department of Pharmacy, University of Rajshahi, Rajshahi-6205, Bangladesh, Tel: +880-721-750244; Fax: +880-721-750064; E-mail: manobendro2218@gmail.com

Received date: September 12, 2017; Accepted date: September 26, 2017; Published date: September 30, 2017

Copyright: (c) 2017 Ray MN, et al. This is an open-access article distributed under the terms of the Creative Commons Attribution License, which permits unrestricted use, distribution, and reproduction in any medium, provided the original author and source are credited.

\begin{abstract}
Diabetes mellitus the one of four priority non-communicable diseases is an important public health issue across the world. The disease is associated with abnormalities in Carbohydrate, Protein and Fat metabolism affecting 422 million adults globally (WHO). Though many antidiabetic agents have been introduced in the modern drug arsenal in the recent past, still diabetes and the related complications continue to be alarming health problem in developed as well as in developing countries. Hopefully, there are many plants has been reported to have potent antidiabetic activity and have been used for a long time in traditional medicine. However, the screening for potent antidiabetic molecule from natural sources is still going on. The antidiabetic activity was evaluated in normal and Streptozotocin (STZ) induced diabetic mice. Remarkable lowering of blood glucose levels $(90.19 \%$ by leaf extract and $76.86 \%$ by bark extract compared to positive control)of the test animals depicts that the methanolic leaf and bark extract exhibited significant property $(P<0.05)$ compared to diabetic control group. Dose dependent effect was also reflected in the test results. Control animals were found to be stable in their body weight while diabetic mice showed significant reduction in body weight during 7 days. The antidiabetic activity produced by a single mechanism or multiple glucose lowering mechanism may be involved.
\end{abstract}

Keywords: Bauhinia acuminata; Leaf; Bark; Methanolic extract; Antidiabetic; Streptozotocin

\section{Introduction}

Diabetes is a chronic metabolic disease condition in which the levels of glucose (sugar) in the blood are too high associated with long term damage, dysfunction and failure of some vital organs like eye, kidneys, heart, liver and blood vessels due to defect in insulin secretion, insulin action or both [1].

Globally, one in 10 adults (347 million people) now has diabetes. Worldwide, 3.2 million deaths are attributable to diabetes every year. One in 20 deaths is attributable to diabetes; 8,700 deaths; every day; six deaths every minute. In developing countries the conditions are more measurable. In developing countries the number of people with diabetes will increase by $150 \%$ in the next 25 years (Diabetes care, 2004). From 1990 to 2013, in this time period the number of deaths from diabetes also rose more than $200 \%$ [2]. However, till now, there is no cure for diabetes but research is going on [3]. So, it is high time to develop new potential remedy against this disease.

There are numerous traditional medicinal plants reported to have hypoglycemic properties such as Allium sativum (Garlic), Azadirachta indica (Neem), Vinca rosea (Nayantara), Trigonella foenum (Fenugreek), Momordica charantia (Bitter ground), Ocimum santum (Tulsi) and so on. Many of these are less effective in lowering glucose levels in severe diabetes [4-6].

Bauhinia acuminata (Family: Fabaceae) is a species of flowering shrub native to tropical southeastern Asia. Common names include: Dwarf White Bauhinia, White Orchid-tree and Snowy Orchid-tree.
Traditionally, the leaves and bark of $B$. acuminata have been widely used for various medicinal purposes (eg. a remedy of gonorrhoea, common cold cough, used to treat burns, biliousness etc.) $[7,8]$. Remarkable antidiabetic activity has been reported on different species of Bauhinia genus like Bauhinia purpurea, Bauhinia variegata. The present study was carried out to study antidiabetic effect of leaf and bark of Bauhinia acuminata.

\section{Materials and Methods}

\section{Plant material}

The medicinal plant Bauhinia acuminata (Local name- Shet Kanchon) was collected from the campus of University of Rajshahi, Bangladesh and from the medicinal plant garden of Bangladesh Agricultural University (BAU), Mymensing, Bangladesh. The authenticity of the plant was identified by Mr. AHM Mahbubur Rahman, Associate Professor, Department of Botany, and University of Rajshahi, Bangladesh. The fresh leaves and bark were collected and washed with water to clean the dirt. The plant parts were dried under mild sun and grinded with an electric grinder into coarse powder and used for cold extraction.

\section{Extraction procedure}

The coarse leaf and bark powder was macerated with methanol for 7 days with occasional shaking and stirring. The solvent was evaporated by using rotary evaporator under reduced pressure at $50^{\circ} \mathrm{C}$ temperature [9]. The crude extract such obtained was tested for its antidiabetic activity. 
Citation: $\quad$ Ray MN, Naz T, Khan A, Ali MH (2017) Antidiabetic Potential of Methanolic Extract of Leave and Bark of Bangladeshi Medicinal Plant

Page 2 of 3

\section{Drugs}

Streptozotocin was bought from Sigma Aldrich, Germany and Comet 500 Tablet of Square Pharmaceuticals, Bangladesh was used as source of Metformin Hydrochloride.

\section{Animals}

A total number of 60 Swiss albino female mice weighing about 25-30 g and 2 month aged were purchased from animal's house of International Centre for Diarrhoeal Disease Research, Bangladesh (ICDDR, B). Prior to starting of the experiment, all the mice were allowed to adapt with the new environmental conditions for a period of two week. During the experimental period the mice were kept in a well-ventilated animal house at room temperature of $25^{\circ} \mathrm{C}$ and $\% \mathrm{RH}$ of $60-70 \%$. Animals described as fasted were deprived of food for $16 \mathrm{~h}$ but had free access to water. This fasting condition may have impact on lipid metabolism but we believe that it has minor impact on blood glucose metabolism. All the mice were kept in cages with wide square mesh at bottom to avoid coprophagy and maintained with natural 12 hour light and dark cycle.

\section{Sample collection}

Blood samples were collected by tail artery puncture method and blood glucose levels were estimated using an electronic glucometer [10].

\section{Statistical analysis}

The result was expressed as Mean \pm SEM. Comparison between the groups was made by ANOVA (Analysis of variance). A value of $\mathrm{P}<0.05$ was considered significant.

\section{Result}

\section{Effect of Bauhinia acuminata leaf and bark extract on} streptozotocin induced diabetes mellitus

Diabetes was induced in mice by injecting intraperitonially a freshly prepared solution of streptozotocin $(30 \mathrm{mg} / \mathrm{kg})$ in citrate buffer after baseline glucose estimation was done while a group of 5 identical mice was kept without Streptozotocin which categorized as normal control (Group-1). After 72 hours of Streptozotocin administration the blood sample was collected by tail artery puncture method and glucose level was determined by glucometer to confirm diabetes. Mice with postprandial blood glucose levels above $10.8 \mathrm{mmol} / \mathrm{L}$ were selected for the study [11]. The diabetic mice were again subdivided into 7 groups as follows:

Group 2 Diabetic control

Group 3 Diabetic + DMSO $(500 \mu \mathrm{l} / \mathrm{kg} /$ day $)$

Group 4 Diabetic + metformin $(100 \mathrm{mg} / \mathrm{kg})$

Group 5 Diabetic + methanolic extract of leaf $(25 \mathrm{mg} / \mathrm{kg})$

Group 6 Diabetic + methanolic extract of leaf (50 mg/kg)

Group 7 Diabetic + methanolic extract of bark $(100 \mathrm{mg} / \mathrm{kg})$

Group 8 Diabetic + methanolic extract of bark $(200 \mathrm{mg} / \mathrm{kg})$

The number of animals in each group is determined by using the "Resource Equation Method" [12]. The treatment started after 3 days of diabetes confirmation to allow the diabetic condition to establish.

Administration of STZ (30 mg/kg, i.p.) led to many folds elevation of Post-prandial blood glucose levels. The treatment was given orally. A week of daily treatment of methanolic extract of leaf and bark of $B$. acuminata led to a dose-dependent fall in blood sugar levels (Table 1). Vehicle control animals were found to be stable in their body weight but diabetic mice showed significant reduction in body weight during 7 days. The effect of methanolic leaf and bark extract of Bauhinia acuminata on glucose level in STZ induced diabetic mice had been summarized in Table 1. A 7 days treatment schedule was selected to monitor the result on weekly basis (Figure 1).

\begin{tabular}{|l|l|l|}
\hline \multirow{2}{*}{ Groups } & Glucose Levels (mmol/L) \\
\cline { 2 - 3 } 1. Normal control & Prior Treatment & After 7 days \\
\hline 2. STZ induced diabetic control & $5.82 \pm 0.27$ & $6.66 \pm 0.59$ \\
\hline 3. Diabetic + DMSO $(500 \mu / \mathrm{kg} /$ day $)$ & $18.54 \pm 0.88$ & $25.76 \pm 2.21$ \\
\hline 4. Diabetic + Metformin $(100 \mathrm{mg} / \mathrm{kg} /$ day $)$ & $11.32 \pm 0.66$ & $14.85 \pm 2.15$ \\
\hline 5. Diabetic + Methanolic extract of leaf $(25 \mathrm{mg} / \mathrm{kg} / \mathrm{day})$ & $20.18 \pm 2.93$ & $9.98 \pm 0.80$ \\
\hline 6. Diabetic + Methanolic extract of leaf $(50 \mathrm{mg} / \mathrm{kg} / \mathrm{day})$ & $19.68 \pm 2.88$ & $13 \pm 2.54$ \\
\hline 7. Diabetic + Methanolic extract of bark $(100 \mathrm{mg} / \mathrm{kg} / \mathrm{day})$ & $22.9 \pm 2.49$ & $13.7 \pm 2.41$ \\
\hline 8. Diabetic + Methanolic extract of bark $(200 \mathrm{mg} / \mathrm{kg} / \mathrm{day})$ & $18 \pm 2.47$ & $10.84 \pm 1.88$ \\
\hline
\end{tabular}

Table 1: Effect of methanolic leaf and bark extract of Bauhinia acuminata on glucose level in STZ induced diabetic mice. 
Citation: $\quad$ Ray MN, Naz T, Khan A, Ali MH (2017) Antidiabetic Potential of Methanolic Extract of Leave and Bark of Bangladeshi Medicinal Plant Bauhinia acuminata L on Mice . J Diabetes Metab 8: 762. doi:10.4172/2155-6156.1000762

Page 3 of 3

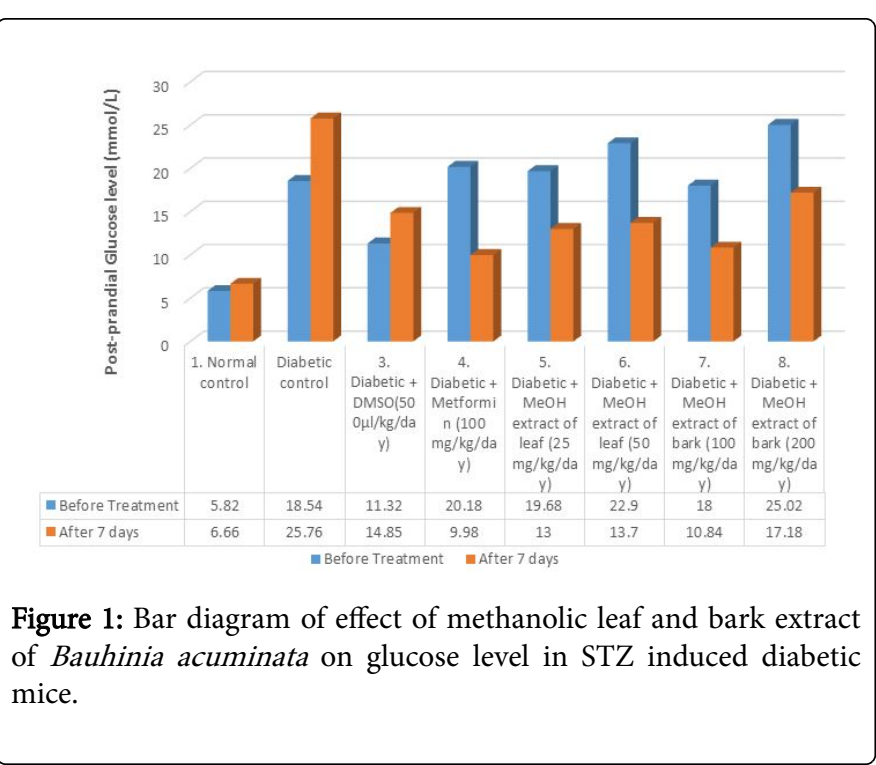

\section{Discussion and Conclusion}

Our study revealed that, in comparison to positive standard, metformin-HCL $(100 \mathrm{mg} / \mathrm{kg})$ methanolic extract leaves in lower doses $(25 \mathrm{mg} / \mathrm{kg}$ and $50 \mathrm{mg} / \mathrm{kg}$ ) produced a promising glucose lowering property. The methanolic extract of leaves lowered blood glucose to $65.49 \%$ and $90.19 \%$ at a dose of $25 \mathrm{mg} / \mathrm{kg}$ and $50 \mathrm{mg} / \mathrm{kg}$ respectively compared to the standard. The blood glucose level of treatment group was compared with the diabetic control group ( $\mathrm{p}$ value $<0.05$ ). On the other hand, methanolic extract of bark of our experimental plant also showed a significant glucose lowering property of $70.19 \%$ and $76.86 \%$ at dose $100 \mathrm{mg} / \mathrm{kg}$ and $200 \mathrm{mg} / \mathrm{kg}$ respectively compared to the positive control. Comparatively leaves extract was found to be more potent than the bark extract as it produced a remarkable effect at lower doses.
The major side effect of the treatment is assumed to be hypoglycemia. However, it is believed that our research will be helpful for future research like compound isolation and biological activity of the pure compound. It will be great if this plant provide us a new potent lead.

\section{References}

1. http://www.who.int/mediacentre/factsheets/fs194/en/.

2. WHO (2007) Bangladesh-Communicable Disease report.

3. Sumana G, Suryawashi SA (2001) Effect of Vinca rosea extracts in treatment of alloxan diabetes in male albino rats. Indian J Exp biol, 39: 748-759.

4. Holman RR, Turner RC (1991) Oral agents and insulin in the treatment of NIDDM. In: Pickup J, Williams G (Eds) Blackwell, Oxford, UK pp: 467-469.

5. Rao BK, Kesavulu MM, Apparao CH (2001) Antihyperglycemic activity of Momordica cymbalaria in alloan diabetic rats. J Ethnopharmacol 78: 67-71.

6. Ahmed MF, Kazim SM, Ghori SS, Mehjabeen SS, Ahmed SR, et al. (2010) Antidiabetic activity of Vinca rosea extracts in alloxan-induced diabetic rats. International J Endocrinol 2010: 1-6.

7. Nageshwar G, Anuradha SMJ, Radhakrishnaiah M, Narayana LL (1986) Distribution pattern of Phenolic constituents in the species of Bauhinia Linn and its taxonomic significance. Proc Indian Acad Sci (Plant Sci) 96: $1-7$

8. Nageshwar G, Radhakrishnaiah M, Narayana LL (1984) Numerical chemotaxonomy of Bauhinia. Proc Indian Acad Sci (Plant Sci) 93: 621627.

9. Naher N, Khurshid-Alam AHM, Islam S (2012) Effects of Acacia nilotica leaf extract on Adrenaline induced hyperlipidemia and cardiac remodeling in rats. Bangladesh Pharmaceutic J 15: 135-139.

10. Hoff J (2000) Methods of blood collection in the mouse. Lab Animal 29:10

11. Liang XC, Xie MZ, Guo SS (1993) Clinical and experimental study on effect of jin-qi-jiang-tang-pian or qi-yin deficiency and hyperactivity of diabetes mellitus. Ch J Integ Trad West Med 13: 587-590.

12. https://dx.doi.org/10.4103\%2F0976-500X.119726. 